\title{
The effect of vitamin $\mathrm{E}$ on the quality of meat of pigs fed maize grain silage
}

\author{
M. Świątkiewicz ${ }^{1}$ and E. Hanczakowska \\ National Research Institute of Animal Production, \\ Department of Animal Nutrition and Feed Science \\ 32 -083 Balice, Poland
}

\begin{abstract}
In an experiment carried out on 48 fattening pigs the effects of adding vitamin $\mathrm{E}$ to maize grain silage fed during the whole fattening period from 60 to $111 \mathrm{~kg} \mathrm{BW}$ on meat quality and storage stability were studied. Pigs originated from PL $\times$ LWP sows mated to a D $\times$ Pi boar were fed restrictively according to body weight. All animals received the same daily amounts of maize grain silage and soyabean meal, but the diet for group II was supplemented with vitamin E. Vitamin E supplementation slightly improved meat quality traits and significantly $(\mathrm{P} \leq 0.05)$ improved meat shelf-life during frozen storage.
\end{abstract}

KEY WORDS: maize grain silage, vitamin E, pork quality

\section{INTRODUCTION}

Over the last two years the use of farm-grown feeds in pig fattening has attracted growing attention for economic reasons. Maize grain, characterized by a high energy concentration, nutrient digestibility, lack of antinutritive factors, and satisfactory yields is recommended, particularly in the form of grain silage. The expected cost reduction can be obtained especially when this silage is fed up to the end of the fattening period. The high content of unsaturated fatty acids in maize grain creates problems with meat quality and stability during storage. This kind of diet influences the meat fatty acid profile and stimulates lipid oxidation processes (D'Arrigo et al., 2002), which generate undesirable organoleptic characteristics such as odour, taste and colour as well as decrease the shelf-life of meat shortly after slaughter. Meat and fat quality can be protected from these oxidation products either by limiting this kind of diet before slaughter (Sommer, 1994; Burgstaller, 1995) or by supplementing it with higher doses of the biological antioxidant, vitamin E (Jensen et al., 1998).

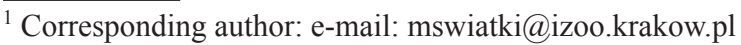


The aim of this experiment was to investigate the effectiveness of adding vitamin $\mathrm{E}$ to maize grain silage fed to pigs during the entire fattening period on meat quality and stability.

\section{MATERIAL AND METHODS}

The experiment was carried out on 48 pigs originated from Polish Landrace $\times$ Large White Polish sows mated to a Duroc $\times$ Pietrain boar, and divided into two restrictively fed groups according to body weight from approximately 60 to $111 \mathrm{~kg}$. For the whole fattening period, group I received crushed maize grain silage in amounts of 2.2-2.8 kg daily and, as the protein component, soyabean meal ( 0.6 to $0.5 \mathrm{~kg} / \mathrm{d})$. For pigs in group II the same diet was supplemented with $600 \mathrm{mg}$ of vitamin $\mathrm{E}$ per $\mathrm{kg}$ of soyabean meal. Daily feed rations for pigs in both groups were supplemented with vitamins and minerals. All animals were kept in individual, straw-bedded pens. At the end of the experiment all of the pigs were slaughtered, right sides of carcasses were evaluated and samples of longissimus dorsi muscle, obtained from the area of the last thoracic and first lumbar vertebra, were collected for basic chemical analysis (AOAC, 1990), TBA-RS content (Pikul et al., 1989) and fatty acid profile (gas chromatograph Varian 3400). Backfat samples were taken from the same place for peroxide value estimation (AOAC, 1990). TBA-RS, peroxide value and meat colour (colourimeter Minolta CR-310) were measured after 2 weeks and 4 months of storage at $-25^{\circ} \mathrm{C}$. All data were subjected to analysis of variance (Statistica, 1997).

\section{RESULTS}

The results presented in Table 1 indicate that maize silage supplemented with vitamin E had no effect on pigs' carcass quality. All measured parameters were slightly better in pigs receiving vitamin $\mathrm{E}$, but the differences were not statistically significant.

Table 1. Results of carcass quality evaluation

\begin{tabular}{|c|c|c|c|}
\hline \multirow[b]{2}{*}{ Item } & \multicolumn{2}{|c|}{ Experimental groups } & \multirow[b]{2}{*}{ SEM } \\
\hline & $\begin{array}{l}\text { I - maize grain } \\
\text { silage }\end{array}$ & $\begin{array}{c}\text { II - maize grain } \\
\text { silage with vitamin } \mathrm{E}\end{array}$ & \\
\hline Body weight at slaughter, kg & 111 & 111 & 0.282 \\
\hline Meat content in primal cuts, $\mathrm{kg}$ & 26.08 & 26.25 & 0.477 \\
\hline Meat in proper ham, \% & 75.18 & 75.38 & 0.778 \\
\hline Loin eye area, $\mathrm{cm}^{2}$ & 59.02 & 59.39 & 1.754 \\
\hline Carcass meatiness, $\%$ & 58.73 & 60.07 & 0.873 \\
\hline Backfat thickness of 5 measurements, $\mathrm{cm}$ & 2.42 & 2.37 & 0.066 \\
\hline
\end{tabular}

Some of the meat quality and stability parameters assessed in the present experiment are given in Table 2. The chemical composition of M. longissimus dorsi 
was similar in both groups. The vitamin E-supplemented maize silage increased the polyunsaturated fatty acid content in meat by $1.9 \%$, but the differences were not significant. A tendency towards improved (by 1.7 to $3.33 \%$ ) meat redness and yellowness, measured after 2 weeks and 4 months of storage, was observed in pigs receiving vitamin E. Supplementation of the maize silage with vitamin E significantly $(\mathrm{P} \leq 0.05)$ decreased the peroxide value and TBA-RS content in meat after 4 months of frozen storage by approximately 36 and 18\%, respectively in comparison with the unsupplemented group.

Table 2. Some indices of $M$. longissimus dorsi meat quality and stability

\begin{tabular}{lccc}
\hline & \multicolumn{2}{c}{ Experimental groups } \\
\cline { 2 - 3 } Item & $\begin{array}{c}\text { I - maize grain } \\
\text { silage }\end{array}$ & $\begin{array}{c}\text { II - maize grain silage } \\
\text { with vitamin E }\end{array}$ & SEM \\
\hline Crude protein content, \% & 23.08 & 23.40 & 0.129 \\
Crude fat content, \% & 1.97 & 1.78 & 0.144 \\
PUFA, \% & 21.64 & 22.05 & 1.075 \\
Meat colour on Hunter scale after 2 weeks & & & \\
$\quad$ lightness & 44.58 & 45.40 & 0.590 \\
$\quad$ redness & 12.86 & 13.08 & 0.120 \\
$\quad$ yellowness & 2.40 & 2.32 & 0.103 \\
Meat colour on Hunter scale after 4 months & & & \\
$\quad$ lightness & 42.94 & 44.63 & 0.561 \\
$\quad$ redness & 12.29 & 12.69 & 0.121 \\
$\quad$ yellowness & 3.62 & 3.52 & 0.106 \\
Peroxide value after 2 weeks, meq $/ \mathrm{kg}$ & 0.473 & 0.401 & 0.056 \\
Peroxide value after 4 months, meq/kg & $0.959^{\mathrm{b}}$ & $0.614^{\mathrm{a}}$ & 0.075 \\
TBA-RS after 2 weeks, $\mathrm{mg} / \mathrm{kg}$ & 0.457 & 0.454 & 0.014 \\
TBA-RS after 4 months, $\mathrm{mg} / \mathrm{kg}$ & $0.625^{\mathrm{b}}$ & $0.510^{\mathrm{a}}$ & 0.028 \\
\hline
\end{tabular}

a,b- $\mathrm{P} \leq 0.05$

\section{DISCUSSION}

The main hypothesis examined in the present experiment was the possibility of improving the quality and storage stability of meat from pigs fed high amounts of maize grain silage to the end of the fattening period. The obtained results indicate a tendency towards improved carcass and meat quality in pigs fed maize grain silage with added vitamin E, but the differences were not significant. Supplementation prevented the meat from yellowing and increased meat redness after frozen storage, which is always desired by consumers (Jensen et al., 1998). Meat colour stabilization agrees with the findings obtained by the present author in a previous experiment (Hanczakowska, 2004) as well as in other studies (Monahan et al., 1992). The antioxidative role of vitamin $\mathrm{E}$ was confirmed by a 
slight upward tendency in the PUFA content of meat. The iodometric peroxide value is used as the main indicator of the initial phases of unsaturated fatty acid oxidation, while a typical indicator of the secondary products of lipid oxidation is 2-thiobarbituric acid-reactive substances (TBA-RS). Both indices demonstrate that vitamin $\mathrm{E}$ is 56 and $66 \%$ effective in inhibiting lipid oxidation processes at the initial and final phase, respectively. Similar vitamin E activity was also noted by D'Arrigo et al. (2002).

\section{CONCLUSIONS}

The quality and shelf-life of meat obtained from pigs receiving ensiled maize grain for the whole fattening period can be improved by supplementing their diet with the antioxidant, vitamin E.

\section{REFERENCES}

AOAC, 1990. Official Methods of Analysis, Association of Official Analytical Chemists. $15^{\text {th }}$ Edition. Arlington, VA

Burgstaller G., 1995. Limited use of CCM for finishing pigs. Mais 4, 116-119

D’Arrigo M., Hoz L., Lopez-Bote C.J., Cambero I., Pin C., Rey A.I., Ordóñez J.A., 2002. Effect of dietary linseed oil and $\alpha$-tocopherol on selected properties of pig fat. Can. J. Anim. Sci. 82, 339-346

Hanczakowska E., 2004. Effect of natural antioxidants in diets on fattening performance and meat quality in fattening pigs. Thesis. National Research Institute of Animal Production, Kraków (Poland) (Editor)

Jensen C., Lauridsen C., Bertelsen G., 1998. Dietary vitamin E: Quality and storage stability of pork and poultry. Trends Food Sci. Technol. 9, 62-72

Monahan F.J., Asghar A., Gray J.I., Buckley D.J., Morrissey P.A., 1992. Influence of dietary vitamin E on the color stability of pork chops. Proceedings of $38^{\text {th }}$ International Congress of Meat Science and Technology. Clermont-Ferrand (France), pp. 543-546

Pikul J., Leszczyński D., Kummerow F.A., 1989. Evaluation of three modified TBA methods for measuring lipid oxidation in chicken meat. J. Agr. Food Chem. 37, 1309-1315

Sommer W., 1994. Have CCM (maize cob mix) and maize grain any effect on fat and meat quality. Mais 3, 108-111

\section{STRESZCZENIE}

\section{Wpływ dodatku witaminy E na jakość mięsa świń żywionych kiszonym ziarnem kukurydzy}

W doświadczeniu przeprowadzonym na 48 tucznikach określano wpływ dodatku witaminy $\mathrm{E}$ do dawek dla świń żywionych kiszonym ziarnem kukurydzy przez cały okres tuczu od 60 do 111 $\mathrm{kg}$ m.c. na jakość i trwałość mięsa. Tuczniki pochodzące od loch (wbp $\times$ pbz) pokrytych knurem $(\mathrm{D} \times \mathrm{Pi})$ żywiono ograniczonymi dawkami paszy odpowiednio do masy ciała. Wszystkie zwierzęta otrzymywały taką samą dzienną dawkę kiszonego ziarna kukurydzy i śruty sojowej, ale dla grupy II zastosowano dodatek witaminy E. Dodatek witaminy E do dawek pokarmowych polepszył nieco badane cechy jakości mięsa oraz istotnie $(\mathrm{P} \leq 0,05)$ poprawił trwałość mięsa w czasie mrożenia. 